\title{
THE PROFESSIONALIZATION OF FESTIVAL ORGANIZATIONS: A RELATIONAL APPROACH TO KNOWLEDGE MANAGEMENT
}

\author{
RAPHAELA STADLER, SIMONE FULLAGAR, AND SACHA REID \\ Department of Tourism, Sport and Hotel Management, Griffith University, Nathan, Australia
}

\begin{abstract}
In this article we examine the emergence of knowledge management (KM) within the professionalization of festivals and events. The growing complexity of festival management places pressure on organizations to effectively manage "knowledge" in order to succeed. Knowledge is commonly conceptualized as information that can be stored or itemized through checklists. We offer an alternative conceptualization of KM as a relational construction shaped by the organizational culture and structure. We develop this relational approach through a case study of the Queensland Music Festival (QMF) to examine the construction of KM roles and responsibilities. Our ethnographic research and qualitative analysis identifies how QMF implicitly utilizes chief knowledge officer, knowledge broker, and knowledge worker roles. These roles were successfully performed over a short duration and yet they were not defined or explicitly stated. We discuss how the culture and spatial organization of work teams contributed to a collective understanding of the value of sharing and creating knowledge. With growing professionalization we argue that festival organizations will increasingly develop a more self-conscious awareness of the significance of KM language and practice. The findings will enable festival managers to better understand how KM processes are embedded within an organizational culture and contribute to organizational learning.
\end{abstract}

Key words: Knowledge management; Festival organizations; Professionalization; Organizational culture; POD structure

Introduction

The growth and diversity of music festivals (Hede \& Rentschler, 2008) has led to a highly competitive external environment and a host of internal challenges for event managers (Getz \& Andersson, 2008). The professionalization of the industry has added a further level of management complexity and increased pressure on festival and event organizations. As Morgan (2009) noted, "The first and most fundamental success factor is operational and administrative efficiency" (p. 82, emphasis in original). In this article we examine how effective knowledge management is one domain that can assist festival organizations to achieve operational efficiency and effectiveness (Dalkir, 2005; Debowski, 
2006; Nonaka \& Takeuchi, 1995). Over the past two decades it has been argued within the broader organizational literature that knowledge is the key differentiating factor in organizations and that knowledge management is important for long-term success. Knowledge management is the process and "capability of a company as a whole to create new knowledge, disseminate it throughout the organization, and embody it in products, services and systems” (Nonaka \& Takeuchi, 1995, p. 3). Within the context of event management the academic focus on knowledge is an emerging area of research and growing area of practice in the era of professionalization.

Effective knowledge management policies, processes, and practices assist event organizations in achieving their economic, cultural, and creative outcomes. The professional roles of event management staff who create, organize, and transfer knowledge are also central to ensuring music festivals remain innovative and competitive in the long run. Yet, there has been little research undertaken to explore how music festival organizations and their staff think about and manage knowledge in the context of professionalization. To further understanding of knowledge management practices this article draws upon a case study of a large, multievent festival organization, the Queensland Music Festival (QMF). The research aimed to identify how festival staff (permanent and seasonal) perceived their roles and responsibilities in the knowledge management process. Second, the research examined how the organizational structure and culture of the festival importantly created the basis for a shared understanding of knowledge management processes and practices. The findings aim to contribute to the professional development of festival management by highlighting how knowledge management is embedded in an organizational culture that supports new ideas, knowledge creation, and organizational learning.

\section{Literature Review}

Knowledge management as a concept and set of practices has been constructed from different perspectives in the literature that place emphasis on technological, organizational, or relational dimensions (Heisig, 2009). Within the festival and event management literature the importance of knowledge management has been acknowledged (Allen, O’Toole, McDonnell, \& Harris, 2011; Getz, 2007). However, the emphasis in this field has largely been on documenting and storing knowledge; thus, knowledge is most commonly constructed as having technological and "asset"-like properties.

The "technological" construction of knowledge management focuses on knowledge transfer and knowledge documentation issues that can be enhanced through technology, such as emails, databases, internal blogs or wikis, or other knowledge management systems (Alavi \& Leidner, 2001; Schütt, 2003). More recently, information and knowledge documentation in databases and checklists has been closely examined within an event context. The documentation of knowledge in manuals and checklists is regarded as crucial (Hanlon \& Jago, 2009; Tourism \& Events Queensland, 2013), particularly in the running of mega-events such as the Olympics. Chappelet (2000), for example, stresses the importance of training volunteers, and writing and distributing manuals among employees. During the Sydney Olympic Games 2000 a systemthe Transfer of Olympic Knowledge (TOK)—was established, through which tacit knowledge could be turned into formal knowledge and manuals that could be shared between organizations. TOK enabled the subsequent Games to benefit from the lessons learned during the Sydney event. Effective knowledge management, therefore, involves translating tacit knowledge that has not been consciously identified as it is "tied to the senses, tactile experiences, movement skills, intuition, unarticulated mental models, or implicit rules of thumb" (Nonaka \& Von Krogh, 2009, p. 636). Singh and Hu (2008) examined knowledge exchange between the Athens Organizing Committee and the Greek National Tourism Organization during the 2004 Athens Olympic Games. They found that both institutions created a large amount of knowledge and also shared some of it, highlighting the importance of transferring different kinds of knowledge to future organizing committees. Although very valuable, such knowledge-sharing programs require a lot of resources, and are thus difficult to implement in small or medium-sized festival organizations. Furthermore, they construct knowledge primarily as an asset.

The "organizational" focus includes research on organizational structures and designs that help 
facilitate knowledge management via formal as well as informal groups, PODs, and communitiesof-practice (Fenton \& Albers, 2007; Lave \& Wenger, 1991; Szulanski, 2000; Wenger, 1998; Wenger, McDermott, \& Snyder, 2002). In the broader literature Albers and Brewer (2003) in particular highlight the importance of group structures that focus on diversity among group members to enhance knowledge creation and transfer. In addition, Fenton and Albers (2007) maintain that best practices developed within one POD or team should ideally be applied across other teams as well as the organization as a whole. In the event literature Getz (1998) examined information sharing and knowledge development between festival organizations. He found that most festival managers largely relied on active participation, or "learning through doing," and through observation of other festivals and event practitioners. Managers conducted comparisons across areas such as programming, marketing, fund-raising, and ticket sales with emphasis being placed on information and knowledge transfer between different festivals, rather than within the festival organization itself.

Another study focusing on the organizational dimension of knowledge management was conducted by Abfalter, Stadler, and Müller (2012) with one small festival organization in Colorado. The authors explored how the development of a community-of-practice across the festival team involved several levels of participation and involvement with the organization. This informal and flexible structure proved successful in terms of sharing knowledge with new and seasonal staff members within the festival organization. The study revealed that both formal and informal ways of sharing knowledge with newcomers in temporary festival organizations are essential for the acquisition of organizational knowledge and "this is particularly important during increases in staff turnover and shifts in the relation between keepers of knowledge and newcomers" (Abfalter et al., 2012, p. 13). The study is centered on knowledge-sharing activities and strategies through a focus on how a community-of-practice structure enables participation and involvement during the festival season and knowledge sharing practices with new staff members.

The third perspective develops a "relational" focus on the "soft" factors of knowledge management, such as people, organizational culture, interaction and communication, relationships, trust, power, and motivation (Ardichvili, Page, \& Wentling, 2003; Blackler \& McDonald, 2000; DeLong \& Fahey, 2000; Huemer, von Krogh, \& Roos, 1998; O’Dell, 2004; Osterloh \& Frey, 2000; Yang, 2007). The relational focus of knowledge management pays attention to knowledge as it is produced and shared by staff members in different roles. Hence, it is crucial for festival organizations to understand how employees interpret and share the knowledge they carry around "in their head" within the time-pressured context of organizing an event (Van der Wagen, 2007, p. 31). With the temporal, "pulsating" nature (Hanlon \& Cuskelly, 2002; Hanlon \& Jago, 2009) of festivals there are few permanently employed staff members and many seasonal staff members. Festival organizations thus grow and contract quickly in relation to the stage of the event life cycle. In this organizational environment knowledge about event operations and key relationships has to be shared quickly and efficiently with and between a diverse range of individuals. Furthermore, seasonal staff members are likely to move on to other organizations once the festival is over, resulting in loss of corporate knowledge.

The growth of event management as a professional domain (Mair, 2009) has increased expectations that festival managers will become more knowledgeable about organizational culture and processes such as human resources, strategic planning, team communication, event operations, finance, etc. (Junek, Lockstone, \& Mair, 2009). In addition, managers must also coordinate and integrate the roles, responsibilities, and professional expertise of seasonal staff members and contractors (Van der Wagen, 2007). Crucial to the success of a festival is the understanding that all staff have about the nature and scope of their individual roles and organizational responsibilities. Townley (1993) argues that specific job roles are usually articulated in job descriptions, task specifications, and even training specifications. However, job descriptions provide only one source of information about event roles for employees. Staff have to interpret their specific job-related tasks and relationships through the norms, practices, and discourses that construct the organizational culture of the festival. In terms of specific knowledge management roles within festival organizations, historically there has been little explicit recognition of jobs, or job titles, 
despite professionalization. As Getz (2007) argues, "Event managers are already expected to conduct themselves as professionals" (p. 288). However, the implicit way in which festivals practice knowledge management provides a number of challenges for managers and staff who are often employed on short-term contracts. Specifically, there is a need for effective communication between staff with different expertise, greater clarity about role expectations in complex environments, and reflection on how to utilize and share staff insights to enable efficiency and innovation within festival organizations.

Human resource management within festivals has also been identified as significant in knowledge management research (Currie \& Kerrin, 2003; Gloet \& Berrell, 2003; Yahya \& Goh, 2002). Event organizers are reliant upon an individual's previous professional experiences rather than on training, due to time limitations in organizing and planning events. Therefore, the opportunity to train and develop knowledge management skills is limited. This is a particular challenge with volunteers, but also with other staff members, because most event training and learning is on the job (Van der Wagen, 2007). Furthermore, "pulsating” festival organizations rely on the expertise of various stakeholders in dealing with certain aspects of the festival. Hanlon and Jago (2009) argue that the management of these teams and relationships can be challenging as they are unstable and volatile and "based more upon high levels of adrenalin, passion and commitment than on the process of establishing long-term working relationships” (p. 96). Hence, there are numerous challenges for event managers in relation to how to mobilize human resources, undertake professional development, and ensure effective communication between staff with the heightened intensity of different phases in the festival life cycle.

Through our review of the literature we argue that the process of knowledge creation and transfer involves far more than "information" management, databases, and checklists (McElroy, 2003); it is also influenced by relationships and networks within and beyond the organization. In addition, the effective management of knowledge is connected to the festival culture and the exercise of power through staff roles and relationships that can facilitate or constrain knowledge transfer (Clarke \& Jepson, 2011; Foucault, 1980; Townley, 1993). Knowledge is not produced in a vacuum within music festival organizations; rather knowledge is created, managed, and at times contested through the power relations that "govern" the conduct of employees. While workplace hierarchies and formalized roles exist to structure the field of power relations, Foucault and scholars such as Clegg, argue that resistance and regulation produce the lived context of organizational cultures (Clegg, 1998; Foucault, 1980). In this article we extend the "relational" perspective on knowledge management to consider how the festival organization enables or constrains the exercise of power by festival staff as they enact (largely implicit) knowledge management roles.

\section{Knowledge Management Roles and Responsibilities}

One area of knowledge management that has attracted particular attention is concerned with the implementation of identified roles and responsibilities within organizations. Three common knowledge management roles include those of chief knowledge officers, knowledge brokers, and knowledge workers (Earl \& Scott, 1999; Meyer, 2010). Chief knowledge officers are responsible for designing knowledge management systems and processes, and aim to facilitate the transfer and exchange of both explicit and tacit knowledge (Bergeron, 2003; Earl \& Scott, 1999; Schütt, 2003). Burstein, Sohal, Zyngier, and Sohal (2010) further identified KM champions and strategists and argue that they are similar to the chief knowledge officer; however, there can be more than one within an organization. Usually KM champions and strategists have some sort of vision for the organization and are part of the senior management team.

Knowledge brokers can be defined as "people whose job it is to move knowledge around and create connections" (Meyer, 2010, p. 118). It is the knowledge broker's responsibility to facilitate information and knowledge creation and transfer within the organization, as well as connecting people so that they can share knowledge. Knowledge brokers usually have a good understanding of the networks and links within an organization as well as with partners, customers, and other external bodies, and therefore focus more on the relational dimension of knowledge management rather than the 
technological dimension. Knowledge brokers are not necessarily senior managers; they can also be middle managers, with multiple knowledge brokers possible within an organization (Meyer, 2010).

Finally, all employees of an organization can be understood as knowledge workers. Knowledge workers create, share, and use knowledge on a dayto-day basis (Burstein et al., 2010). It can be argued that everyone plays an important role in knowledge management, because "knowledge management cannot be supported by a single librarian or tech support with a toll-free number" (O’Dell, 2004, p. 24). The challenge for an organization is to create a climate and culture that supports and values the input and ideas of all staff regardless of specialization or position within the hierarchy. The scope of these knowledge management roles does figure implicitly within the responsibilities of festival staff; however, they are not explicitly identified for each organizational position. Greater understanding of explicit and implicit knowledge management roles and responsibilities can help staff members to utilize their professional expertise and at the same time develop new skills in the era of professionalization. To examine these knowledge management roles and responsibilities within an event organizational context an ethnographic study of the QMF was undertaken.

\section{The Queensland Music Festival}

The QMF vision is to "transform lives through unforgettable musical experiences” (QMF, 2011). It is a 17-day-long, biennial music festival taking place in Brisbane and regional communities all over the state of Queensland. The QMF was chosen as a case study for this project because it can be seen as a "unique case" in terms of knowledge management. First, the festival is not bound to one specific location, but rather spreads over the entire state of Queensland. Knowledge is therefore dispersed and localized in different communities, which makes knowledge management very difficult for the organization. Secondly, the QMF takes place biennially and involves extensive forward planning with community stakeholders, which is central to the temporal aspect of knowledge management. While this timeframe enables the festival to greater time to create new knowledge in the planning phase, it also means that significant knowledge can be lost with staff changes in the core, contract, and voluntary roles. The first author gained approval from the executive director of QMF to conduct the ethnographic research and subsequent approval was provided by the QMF board of directors who fully supported the project. The research was also approved by the Griffith University Human Ethics Committee.

QMF presents a variety of musical styles, local as well as national and international artists, with a central focus on community participation that is both geographical and cultural. Many artistic projects undertaken with communities are longterm collaborations that tell local stories and define local culture, with the objective of giving back to the community. The community arts values of the festival are central to the festival identity and organizational culture (QMF, 2011). The aim of community arts projects is to engage with members of a community to identify what and how they wish to express their voices, how they want to define themselves and their culture, and to then select the best way of doing so, be it a theatrical performance, a choir, a painting workshop, or any other form of art (Hager, 2008). Community arts bring people together to share and create something of common value (Bartleet, Dunbar-Hall, Letts, \& Schippers, 2010; Derrett, 2003). Such events have the potential to offer long-term social, cultural, and economic value and benefits for areas (Reid, 2008). Kay (2000) furthermore argues that "arts projects are most effective when they are 'owned' by the local community” (p. 423). These arts projects have to be of value for the community, in order to create a collective identity and ownership among community members. Therefore, there is a concentration on the production process, rather than on mere consumption of art (Hawkins, 1991). The QMF is a festival that includes both artistic excellence and community participation in its program. The vision of the festival is to help communities define their own identity and to make their stories heard.

The QMF has a relatively flat organizational structure with seven permanent staff supported by a professional team of producers, project coordinators, technical managers, marketing professionals, and secondments, as well as a logistics coordinator, a ticketing and function coordinator, 
and a receptionist, hired in the lead up and during the event. QMF adopts a typical festival organizational structure, "pulsating” to accommodate festival staff with various backgrounds and skills within tight timeframes to create the festival experience. Within the organizational culture each team is set up in "PODs," consisting of a producer, a project coordinator, and a technical manager, as well as one or two secondments during the festival. The secondments are event management students who support the PODs in their day-to-day practices. Each POD is responsible for a number of events with their own network of contractors, creatives, and artists. Furthermore, there is a marketing professional associated with each event; thus, the different PODs work together with a centralized marketing team as well. This interdisciplinary POD structure and culture is unique to QMF, as many festival organizations develop teams around areas of specialization, such as producers working together as a team and technical staff forming another team. Having interdisciplinary PODs, however, can contribute to the development of an organizational culture that enhances knowledge creation and transfer by emphasizing the relational dimension of knowledge management roles.

\section{Methodology}

This study was guided by a reflexive ethnographic methodology in the design, data collection, analysis, and writing stages. The aim was to make multiple "voices" heard about the perceptions of festival roles and to identify how organizational members construct meaning about knowledge management roles within the QMF from their different positions (Alvesson \& Skoeldberg, 2000). This poststructuralist research approach emphasized how knowledge management roles were constructed from different perspectives within a certain festival culture, context, and history. Within this organizational context the connection between power and knowledge was also made explicit: "It is not possible for power to be exercised without knowledge, it is impossible for knowledge not to engender power" (Foucault, 1980, p. 52). This power-knowledge relation (Foucault, 1977, 1980) has been explored through the first author's immersion in the festival experience and being an insider and outsider at once, which is central to ethnography. Holloway, Brown, and Shipway (2010) argued that ethnographic methods in festival and event research are still underutilized. Quantitative research remains dominant in the field; a small number of qualitative studies focus primarily on the event/festival experience (Cummings, 2007) rather than on the organization behind it. Our ethnographic approach, however, allowed a meaningful engagement with the festival staff (Fullagar \& Pavlidis, 2012) and a suitable examination of the meanings that festival members attribute to knowledge and knowledge management roles within QMF. Through the use of these methods, we aimed to understand knowledge management from an insider perspective.

An interpretation of multiple experiences and meanings of knowledge management and knowledge management roles within QMF combined with the ethnographer's own insights and reflections was the basis for the research design. Our final interpretation of the organizational structure and culture and the different knowledge management roles and responsibilities is, however, not the only "true" interpretation and definitive account; rather it is one possible production of meaning based on the available information, context, and our personal backgrounds (Guba \& Lincoln, 2005; McKee, 2003; Saukko, 2003; Seale, 1999; Snape \& Spencer, 2003).

Within the context of the interpretive research design the QMF served as a single organizational case with multiple units of analysis (selected music performances in particular communities) that enabled an examination of how diverse roles and experiences were understood by participants. Díaz Andrade (2009) argues that case studies are often utilized within positivist approaches to management research and that interpretative design can better facilitate theory building. In this research we situate participant responses with the context of the organizational case study in order to identify how knowledge management is practiced and may be theorized as a relational process. The first author worked together with different members and PODs within the festival organization between February and August 2011, attending various organizational and community events throughout this time period. To explore different views on knowledge management roles within the festival case study three 
methods of data collection were used: ethnography, in-depth semistructured interviews, and textual analysis. Information from the QMF website, the festival brochure, meeting minutes, and other texts was collected and used to contextualize the research participants' responses and the creation of the festival identity. These texts about what the festival promises to be and its sense of community identity are part of the festival discourse. It is therefore important to understand the process of festival management in terms of this discursive level of meaning. This method of textual analysis also helped augment evidence from other sources (i.e., from the first author's observations and interviews) (Hall, 1997; McKee, 2003). Undertaking these three methods over a period of several months helped to track changes within the festival life cycle and to identify changes in the organizational culture over time (Lewis, 2003), which was essential to understanding how shared meaning was created between festival members and in terms of their professional roles (Benton \& Craib, 2001).

The first author spent time with the festival staff at their Brisbane office in order to gain an understanding of how they worked together, shared ideas, created knowledge, and communicated problems and challenges, and thus enacted their roles and responsibilities. This included participation in meetings, workshops, rehearsals, and other key events. The researcher also frequently assisted with small jobs, such as data entry, ticket allocations, mass emails, or follow-up phone calls. During and after all observations field notes were taken. These field notes included descriptions of different settings, events, participants, and the organizational atmosphere, as well as informal discussions with staff members about the process of becoming a member of the festival organization and acquiring organizational knowledge. Going back to these field notes at a later time allowed us to reflect on earlier observations and to identify changes in perceptions and meaning.

A total of 28 in-depth interviews were conducted with a range of participants from different positions, with different responsibilities, from long-term staff members as well as newcomers. A method of "purposive sampling" was used to assure that participants "have particular features or characteristics which will enable detailed exploration and understanding of the central themes and puzzles which the researcher wishes to study" (Ritchie, Lewis, \& Elam, 2003, p. 78). In this particular study this relates to the participants' experiences and roles within the festival organization. Of these 28 interviews, 12 respondents were members of the core staff at the festival office-six permanent and six seasonal staff members, with three respondents interviewed both before and after the festival. Participation in interviews was completely voluntary, with some interviews occurring prior and others during or after the festival in order to cover the temporal dimension of the festival. NVivo was used as a tool for storing, coding, and analyzing the interview transcriptions, field notes, and other texts. Several themes around knowledge management and the QMF organizational culture were identified through the analysis of common "statements" made by participants about professional roles.

It is impossible to capture objective reality in qualitative research, and it was not the goal of our poststructuralist research to discover the one and only "reality" and "truth" about knowledge management roles in festival organizations. A combination of multiple methods, however, provided richness and depth to the issue under research (Denzin \& Lincoln, 2005; Lather, 1993; Lewis \& Ritchie, 2003). We aimed to interpret the meanings that festival staff attribute to their festival roles and to identify the implicit knowledge management responsibilities as part of these festival roles. Richardson (2000) highlights that the insights and stories interview participants gave about their festival experience depend on the discourses available to them. These experiences and discourses are all unique and continuously change. Therefore, it has to be acknowledged that the discourses available to our participants as well as the research team could have been different in terms of where and when the interview was conducted (before, during, or after the festival). Furthermore, Richardson (2000) argues that poststructuralist researchers believe in more than three ways of approaching and understanding the world and thus she introduces the term "crystallization” rather than triangulation as a metaphor for validity. Reality changes whenever the researcher changes the angle or perspective from which he/she looks at it (Saukko, 2003). Through crystallization, therefore, we gained a deep and complex understanding of the 
topic. However, it has to be acknowledged that our understanding is only partial.

\section{Findings}

Through an analysis of observations and interviews we identified how staff members were actively involved in knowledge management in relation to two key themes: the collaborative organizational culture where relationships were highly valued, and the organization of staff roles within an interdisciplinary POD team structure. These two themes identify how a relational understanding of knowledge management contributed to effective knowledge creation and transfer as evidenced in the findings we present below and ensuing discussion.

Consistently staff members emphasized how the QMF organizational culture supported new ideas and innovation, thus providing an opportunity for all staff to contribute. Through this collaborative culture insights and new ideas were generated through staff engagement in the process of creating the festival.

I think it is a very good atmosphere, also a very empowering atmosphere in the core team, which means ... you can say what you think and you can possibly influence things in a way which means that you have a lot of great minds thinking alike and you get a much better outcome. As opposed to just [them] saying "this is what you've got to do." (interview 22, 8/5/11)

A collaborative culture also led to a strong sense of belonging within the team, with some respondents using metaphors, such as, their "QMF family." In terms of knowledge management this importantly demonstrates how the willingness of individuals to share knowledge is enhanced through an organizational culture that values relationships alongside key task-oriented roles (Jo \& Joo, 2011; Thatchenkery \& Chowdhry, 2007).

Collaborative knowledge sharing was also supported by the absence of an overt display of power in the form of hierarchical organizational roles in the QMF office. Different staff roles at QMF were acknowledged by participants and regarded as equally important in the flow of knowledge through the organization. Participants commented on the importance of openness within the organizational culture that made power-knowledge relations more transparent.
You hear stories about other organizations where there is a cultural secrecy and knowledge is power. And I just go like, “what's the point?! It doesn't help anybody!” If you want to bring people on to help you solve problems, you've got to share the information. (interview 27, 8/16/11)

I don't know; it's a hierarchy thing, which doesn't exist here. But I'm sure there are things that [they] don't tell us, but they are things we don't really particularly want to know about anyway. But no one is sitting there, whispering in each other's ears. (interview 4, 6/7/11)

This last statement also demonstrates trust between team members, highlighting that even if certain information is withheld staff trust that this knowledge is not crucial to their role. The combination of a sense of belonging and trust relationships among the team members are key aspects of a collaborative organizational culture at QMF that supports innovation and relational knowledge management by involving all core staff members.

Structurally, the festival headquarters are set up to facilitate this collaborative culture, although there is a clear demarcation of responsibility with senior staff regarded as the key people for knowledge management. When asked who they thought were the key people responsible for knowledge management at QMF, most participants named the executive director and/or a core management team member. The core of permanent staff were viewed as essential to maintaining the continuity of knowledge sharing over time: "it's probably the people who are here all the way through" (interview 5, 6/9/11). The senior staff at QMF also supported collaboration among seasonal staff members through the establishment of distinct roles within different teams who were organized into interdisciplinary PODs within the office space. Careful selection of event professionals was undertaken to ensure staff were able to bring extensive experience to their roles and responsibilities. From a senior management perspective, qualifications in event management were not regarded as highly as demonstrated experience in particular roles (technical, creative, logistical) and a history of strong collaboration:

Everyone is really approachable. If you got questions, you can ask. Yeah, very much so. And everyone is quite comfortable asking for help . . . there 
is no issues. It's kind of one of those rare places where you walk in and if you get your job done, you'll be able to help someone else. They may need you, and vice versa. . . . there's our team and then they work with their own artists and directors and the rest of it. And then there's also the tech guys, they have all their contacts that do their job just for the core of the festival. But I think that all the people here have a lot of respect in the industry. So, Mark and Andy and Alex and Tom, they are all genuine people and they wanna help. You know. (interview 1, 6/2/11)

The emphasis placed upon collaboration and interpersonal relationships as a key aspect of professional roles was viewed as essential to the creation of a shared understanding of the QMF vision and hence a successful festival. A participant commented on how festival knowledge was created and produced through these relationships over time despite staff changes in particular roles,

The fact that the program has grown so much, is a result of consistency, continuity and shared understanding. It's more than just knowledge, its understanding and a shared belief system of what the festival should be. (interview 7, 6/15/11)

It was evident that at QMF there was not a specific or appointed chief knowledge officer. However, there were several staff members who enacted the roles of KM champions and strategists, although not with formalized or official titles. The senior management team and the permanent staff were responsible for the knowledge management processes and for communicating a shared vision. Most importantly, QMF used a very specific hiring strategy to ensure that seasonal team members also embraced this vision and culture and worked together effectively and efficiently. Collaboration was not only considered in relation to specific roles, but also in terms of working relationships and personalities. For example, a producer might be the expert in his or her team, but the composition of the team was considered to be equally important in enabling the flow of knowledge management:

I do take a pride in getting the right person for the job. ... So, we get a project, we work out who the best person for that project is - and that may not necessarily be the producer. It may be the tech manager, okay? So we say, "okay that really fits with that tech manager, let's give it to them, because that's going to be our strongest hand.” And then we form the team around [that person]. . . . We have to look at the way people get on. And you see, well actually both teams in there, the way that [they] work together, they are just like one person, it's amorphous. . . . You can't see the seams; you really can't see the seams, where one area stops and the other area starts. (interview 5, 6/9/11)

The design of PODs within the QMF office proved to be a crucial structure that supported knowledge creation and transfer. During the highpressured time of the festival seasonal staff members took on important knowledge management roles. However, the scope of knowledge management roles was not specified; rather, it emerged out of the organizational culture and the structure of teams within PODs. Individuals working together on particular events not only acted as the links between the permanent staff and the secondments and volunteers, but also between QMF and their contractors and artists.

So the three people working together, me, Veronica and Claire . . . there's a lot of experience put together. Even though she is young, she's done a lot of work. Which goes to how this organization has done its set-up in the PODs. . . . The [other] festivals I've been to and worked with don't do that. They seem to clump technical together, they seem to clump producers together. Now . . that makes absolutely no sense! If you drew that on a diagram, it makes no sense, because ... why? As a technical, I don't need to talk to my other technical managers. I need to talk to my direct show! Our four shows, we talk together. If I need to get information from other technical managers, I stand up, walk over and talk to them. But more than likely, I will be talking to the other two people on my show. . . . So, it's a very good set-up in that way and not many people do that which kind of shocks the hell out of me. (interview 4, 6/7/11)

The unique POD structure at QMF thus resembles the practice of having several knowledge brokers in the organization. Articulating or "naming" these particular knowledge management roles as part of their broader festival role could contribute to greater professionalization and staff development around knowledge creation and transfer. However, a relational understanding of knowledge management also requires a nuanced approach to 
the operation of power within and between staff PODs. While the POD structure has contributed to the collaborative culture of the organization, each POD will generate its own dynamic and hence influence staff members' perceptions of how they belong within the organization and how they perform their roles. The first author identified the differing relationships between each POD (with its unique event responsibilities and team culture) and the overall QMF vision and festival strategy (Leclercqu-Vandelannoitte, 2011).

Today I noticed that the way POD 1 members communicate with each other is quite different from the rest of the team. In POD 1 there are very comedian like characters who work together, they are loud and noisy and always up for a laugh. Their way of communicating is quite intense; they don't bother if others can overhear conversations. Even when I am sitting with them, observing everything they do and listening to everything they say, they don't bother. PODs 2 and 3 are quite different, much quieter indeed. They seem to structure their way of communicating. Sometimes I see them gather in the meeting room to discuss recent issues. (field notes, $7 / 5 / 11$ )

In terms of knowledge management it is important to recognize how the particular power and professional relations (Foucault, 1982) within each POD influence POD members' understanding of their roles and responsibilities, as well as the production of knowledge and engagement in knowledge transfer across the organization. QMF secondments are also placed within these PODs, which leads to a shared understanding between the seasonal staff members and their assistants. Permanent and seasonal staff are in the position to enable or constrain the performance of staff on secondment by providing information and knowledge to assist them to learn "how things are done" at QMF. Despite the potential for conflict, the majority of participants identified how power was exercised in highly productive ways to enable shared understanding of roles and tasks. Through mentoring practices, not only the core team or permanent staff, but also the seasonal staff and their assistants were able to perform the roles of knowledge workers at QMF.

Finally, allowing an outside researcher to join the festival organization for an extended period of time demonstrated how the team was open to another kind of knowledge management role. Meyer (2010) argues that a researcher can also act as a knowledge broker; however, in this particular study, the first author assumed the role of a KM researcher and at times facilitated reflection upon organizational practices. This was not so much a brokering role, but rather through interviews and day-to-day discussion she created an opportunity for individuals to reflect on what they were doing and why. Through this reflexive process the researcher was able to acquire organizational knowledge and also to facilitate a degree of organizational learning through her involvement. In this way the research contributed to the process of professionalization as QMF's understanding of their own approach to knowledge management developed.

I think it's really interesting to have you here as someone to reflect to. . . . I think you've done a great job in terms of becoming visible and engaging with people. So, well done. And I think for us, to have a moment every now and again to take that step back and reflect in this process, is really interesting. (interview 27, 8/16/11)

\section{Discussion}

At QMF knowledge management roles and responsibilities were not expressed and defined for each staff member. Rather, these roles and responsibilities were constructed through a shared understanding of "how things are done" within the festival's organizational structure and culture. At QMF, the employment of professionals, who were very experienced in their specific roles and also valued collaboration, was the basis for effective and efficient working relationships in an otherwise constrained and time-pressured organizational environment. This hiring strategy contributed to high emotional attachment to the organization and a feeling of identification with, and belonging to, the “QMF family” (Jo \& Joo, 2011; Suppiah \& Singh Sandhu, 2011). These findings support Morrison's (1994) argument that staff members define not only their formal roles and job responsibilities, but also assume informal roles that include knowledge management tasks and relationships. However, without explicit identification of such employee contributions to knowledge management, there exists the danger of losing expertise when staff leave, 
undervaluing high staff performance, and miscommunication that can directly affect the relational dimension of knowledge creation and transfer.

Even though the permanent staff members were regarded as the key people responsible for knowledge management at QMF, there was potential for all individuals to contribute. The productive exercise of power was evident in the commitment and contributions of staff members, which enabled QMF to be innovative and enhance competitiveness. A highly successful 2011 festival season with over 90 different partners and sponsors and a 20\% increase in attendance from 2009 was partly the result of this strategy (personal communication). Our research found that the collaborative organizational culture and communication of a common vision were crucial to effective knowledge management practices within the festival. Moreover, at QMF it was recognized that the senior management team were not perceived to have exercised hierarchical power or to have withheld information, which also enhanced the relational knowledge domains of trust, reciprocity, and sharing among organizational participants (O’Dell, 2004). In particular, the design of interdisciplinary teams and POD structures was essential for connecting new and existing knowledge (from contractors and artists) and building bridges within the QMF team and also between QMF and key stakeholders (Getz, Andersson, \& Larson, 2007). The producers, project coordinators, and technical managers who comprised these PODs could thus be regarded as "knowledge brokers," even if this term is not explicitly used within the organization.

Through the creation of PODs these implicit knowledge management roles could be made more explicit to support staff members in taking on knowledge management responsibilities. An explicit discourse about knowledge management within QMF could enhance professionalization and further strengthen the organizational culture that highly values staff contributions. A relational, rather than technical, construction of knowledge could offer QMF another way of articulating a discourse about the role that "knowledge workers" can play to create an innovative festival organization. Even though many of these knowledge management roles are organizationally displaced in the off-season, the collaborative culture within the team allows staff members to continuously share their knowledge and experiences with the permanent staff who are able to critically reflect on effective knowledge management actions and practices for future events. This strategy helps QMF to stay innovative and competitive and become a more self-conscious learning organization (Getz, 2007), which is a crucial step in the professionalization of festival organizations.

\section{Limitations}

This article has examined the knowledge management roles and responsibilities within one festival organization in Australia. The QMF organization has been fairly stable over the last few years with little turnover in full-time staff, and does not rely heavily on volunteer staff. Further research could therefore examine festival organizations of different shapes and sizes and in particular different organizational structures, as the QMF POD structure is not a structure that is utilized in all event types. This would provide a more nuanced understanding of how different festival and event organizational cultures affect knowledge management roles, structures, and perceptions. Researchers taking on different roles within one festival organization could also provide a more detailed and diverse picture of the issue, particularly in terms of board member roles and outsider roles, such as contractors, sponsors, or artists.

\section{Conclusion}

Due to the growth of event management as a professional domain, festival managers as well as seasonal staff members are expected to become more knowledgeable and experienced (Harris, 2004). Effective knowledge management can further enhance the professionalization of the industry. The basis of effective knowledge management in festival organizations rests upon the understanding that staff members have about their role in this process and the organizational culture that supports new ideas and innovation. The challenge for festival managers is to develop a collaborative culture where a shared vision is embraced by individuals and teams. In this way all staff are supported to develop a clear understanding of how they can contribute to an effective and efficient festival organization (Jo \& Joo, 2011; Yang, 2007). The QMF was identified 
in our research as being particularly successful in their "relational" approach to knowledge management in two key areas. First, they developed a collaborative organizational culture where all staff were implicitly encouraged to perform "knowledge broker" and "knowledge worker" roles. Second, collaborative relationships and knowledge sharing were structured through the organization of staff roles within interdisciplinary POD teams. These two themes identify how a relational understanding of knowledge management contributed to effective knowledge creation and transfer.

Knowledge management thus requires more than a conceptualization of knowledge as technological or asset based, although databases and checklists are important tools. This study has shown that the relational dimension of knowledge management, the shared understanding and culture are equally important. However, there is a key question about how effective knowledge management can be incorporated and sustained within festivals as learning organizations. “' 'Pulsating' events have a special challenge to become learning organizations with solid 'memories,' as they have only a few permanent staff” (Getz, 2007, p. 294). There are a number of strategies that festival organizations could develop to improve knowledge management processes and practices. For example, organizations could more explicitly identify and name knowledge management roles and responsibilities (in job descriptions, internal communication, or organizational structures). The relational dimension of knowledge management could be embraced through strategies that aim to capture organizational "stories" such as video, podcast, and other creative formats, in order to communicate them to staff over time. In this sense both core and volunteer staff are a central source of organizational knowledge about how to continuously improve communication and creative collaboration. As other researchers have identified, there exists a range of innovative evaluation processes that could be used to capture and transfer knowledge while retaining the important focus on culture and relationships. Katzeff and Ware (2006), for example, created a video storytelling booth in order to record volunteer workers' stories and personal accounts of their experience and work with the organization, as well as to make their roles visible. A collaborative organizational culture and interdisciplinary POD teams can enhance knowledge management throughout the festival life cycle. With the professionalization of event management there is an opportunity for festivals to benefit from more explicit critical reflection upon how they conceptualize and operationalize knowledge management practices.

\section{Acknowledgment}

We would like to thank the Queensland Music Festival for enabling access and supporting the research process.

\section{References}

Abfalter, D., Stadler, R., \& Müller, J. (2012). The organization of knowledge sharing at the Colorado Music Festival. International Journal of Arts Management, 14(3), 4-15.

Alavi, M., \& Leidner, D. (2001). Review: Knowledge management and knowledge management systems: Conceptual foundations and research issues. MIS Quarterly, 25(1), 107-136.

Albers, J. A., \& Brewer, S. (2003). Knowledge management and the innovation process: The eco-innovation model. Journal of Knowledge Management Practice, 4.

Allen, J., O’Toole, W., McDonnell, I., \& Harris, R. (2011). Festival and special event management (5th ed.). Milton, Australia: Wiley.

Alvesson, M., \& Skoeldberg, K. (2000). Reflexive methodology-New vistas for qualitative research. London/ Thousand Oaks/New Delhi: Sage Publications.

Ardichvili, A., Page, V., \& Wentling, T. (2003). Motivation and barriers to participation in virtual knowledge-sharing communities of practice. Journal of Knowledge Management, 7(1), 64-77.

Bartleet, B.-L., Dunbar-Hall, P., Letts, R., \& Schippers, H. (2010). Sound links-Community music in Australia. Queensland Conservatorium, Griffith University, Brisbane. Retrieved from http://www.griffith.edu.au/_data/ assets/pdf_file/0009/159282/Sound-Links-Book-WebResolution.pdf

Benton, T., \& Craib, I. (2001). Philosophy of social scienceThe philosophical foundation of social thought. Basingstoke/New York: Palgrave.

Bergeron, B. (2003). Essentials of knowledge management. Hoboken NJ: Wiley.

Blackler, F., \& McDonald, S. (2000). Power, mastery and organizational learning. Journal of Management Studies, 37(6), 833-851.

Burstein, F., Sohal, S., Zyngier, S., \& Sohal, A. S. (2010). Understanding of knowledge management roles and responsibilities: A study in the Australian context. Knowledge Management Research \& Practice, 8, 76-88.

Chappelet, J.-L. (2000). Management of the Olympic Games: The lessons of Sydney. OCOG Reports, 43-47. 
Clarke, A., \& Jepson, A. (2011). Power and hegemony within a community festival. International Journal of Event and Festival Management, 2(1), 7-19.

Clegg, S. (1998). Foucault, power and organizations. In A. McKinlay \& K. Starkey (Eds.), Foucault, management and organization theory-from panopticon to technologies of self (pp. 29-48). London/Thousand Oaks/New Delhi: Sage Publications.

Cummings, J. (2007). Sold out! An ethnographic study of Australian Indie Music Festivals. Unpublished doctoral thesis, University of Western Sydney, Sydney.

Currie, G., \& Kerrin, M. (2003). Human resource management and knowledge management: Enhancing knowledge sharing in a pharmaceutical company. International Journal of Human Resource Management, 14(6), 1027-1045.

Dalkir, K. (2005). Knowledge management in theory and practice. Amsterdam: Elsevier.

Debowski, S. (2006). Knowledge management. Milton, Australia: Wiley.

DeLong, D. W., \& Fahey, L. (2000). Diagnosing cultural barriers to knowledge management. Academy of Management Executive, 14(4), 113-127.

Denzin, N. K., \& Lincoln, Y. S. (2005). Introduction-The discipline and practice of qualitative research. In N. K. Denzin \& Y. S. Lincoln (Eds.), Handbook of qualitative research (3rd ed., pp. 1-32). Thousand Oaks, CA: Sage Publications.

Derrett, R. (2003). Festivals \& regional destinations: How festivals demonstrate a sense of community \& place. Rural Society, 13, 35-53.

Díaz Andrade, A. (2009) Interpretive research aiming at theory building: Adopting and adapting the case study design. The Qualitative Report, 14 (1), 42-60.

Earl, M. J., \& Scott, I. A. (1999). Opinion: What is a chief knowledge officer? Sloan Managemenl Review, 40(2), 29-38.

Fenton, D., \& Albers, J. A. (2007). Leveraging knowledge in the sales force of a pharmaceutical company. Journal of Knowledge Management Practice, 8(4).

Foucault, M. (1977). Discipline and punish-The birth of the prison (A. Sheridan, Trans.). New York: Pantheon Books.

Foucault, M. (1980). Power/knowledge-Selected interviews \& other writings 1972-1977 (C. Gordon, Ed.). New York: Pantheon Books.

Foucault, M. (1982). The subject and power. Critical Inquiry, 8(4), 777-795.

Fullagar, S., \& Pavlidis, A. (2012). 'It's all about the journey’: Women and cycle tour events. International Journal of Event and Festival Management, 3(2), 149-170.

Getz, D. (1998). Information sharing among festival managers. Festival Management \& Event Tourism, 5, 33-50.

Getz, D. (2007). Event studies: Theory, research and policy for planned events. Amsterdam: Butterworth-Heinemann.

Getz, D., \& Andersson, T. (2008). Sustainable festivals: On becoming an institution. Event Management, 12, 1-17.

Getz, D., Andersson, T., \& Larson, M. (2007). Festival stakeholder roles: Concepts and case studies. Event Management, 10, 103-122.
Gloet, M., \& Berrell, M. (2003). The dual paradigm nature of knowledge management: Implications for achieving quality outcomes in human resource management. Journal of Knowledge Management, 7(1), 78-89.

Guba, E. G., \& Lincoln, Y. S. (2005). Paradigmatic controversies, contradictions, and emerging confluences. In N. K. Denzin \& Y. S. Lincoln (Eds.), The Sage handbook of qualitative research (3rd ed., pp. 191-215). Thousand Oaks/London/New Delhi: Sage Publications.

Hager, L. L. (2008). Community arts. In G. Carpenter \& D. Blandy (Eds.), Arts and cultural programming-A leisure perspective (pp. 159-172). Champaign, IL: Human Kinetics.

Hall, S. (1997). The work of representation. In S. Hall (Ed.), Representation-Cultural representations and signifying practices (pp. 13-74). London/Thousand Oaks/New Delhi: Sage Publications.

Hanlon, C., \& Cuskelly, G. (2002). Pulsating major sport event organizations: A framework for inducting managerial personnel. Event Management, 7, 231-243.

Hanlon, C., \& Jago, L. (2009). Managing pulsating major sporting event organizations. In T. Baum, M. Deery, C. Hanlon, L. Lockstone, \& K. Smith (Eds.), People and work in events and conventions-A research perspective (pp. 93-107). Oxfordshire/London: CABI.

Harris, V. (2004). Event management: A new profession? Event Management, 9, 103-109.

Hawkins, G. (1991). Reading community arts policy: From Nimbin to the Gay Mardi Gras. In V. Binns (Ed.), Community and the arts-History, theory, practice (pp. 45-54). Leichhardt: Pluto Press Australia Ltd.

Hede, A.-M., \& Rentschler, R. (2008). Mentoring volunteer festival managers: Evaluation of a pilot scheme in regional Australia. In M. Robertson \& E. Frew (Eds.), Events and festivals-Current trends and issues (pp. 56-69). London/New York: Routledge.

Heisig, P. (2009). Harmonisation of knowledge management-Comparing $160 \mathrm{KM}$ frameworks around the globe. Journal of Knowledge Management, 13(4), 4-31.

Holloway, I., Brown, L., \& Shipway, R. (2010). Meaning not measurement-Using ethnography to bring a deeper understanding to the participant experience of festivals and events. International Journal of Event and Festival Management, 1(1), 74-85.

Huemer, L., von Krogh, G., \& Roos, J. (1998). Knowledge and the concept of trust. In G. Von Krogh, J. Roos, \& D. Kleine (Eds.), Knowing in firms-Understanding, managing and measuring knowledge (pp. 123-145). London/ Thousand Oaks/New Delhi: Sage Publications.

Jo, S. J., \& Joo, B.-K. (2011). Knowledge sharing: The influences of learning organization culture, organizational commitment, and organizational citizenship behaviors. Journal of Leadership \& Organizational Studies, 18(3), 353-364.

Junek, O., Lockstone, L., \& Mair, J. (2009). Two perspectives on event management employment: Student and employer insights into the skills requires to get the job done! Journal of Hospitality and Tourism Management, $16,120-129$. 
Katzeff, C., \& Ware, V. (2006). Video storytelling as mediation of organizational learning. Paper presented at the NordiCHI2006: Changing Roles, Oslo.

Kay, A. (2000). Art and community development: The role the arts have in regenerating communities. Community Development Journal, 35(4), 414-424.

Lather, P. (1993). Fertile obsession: Validity after poststructuralism. The Sociological Quarterly, 34(4), 673-693.

Lave, J., \& Wenger, E. (1991). Situated learning-Legitimate peripheral participation. Cambridge: Cambridge University Press.

Leclercqu-Vandelannoitte, A. (2011). Organizations as discursive constructions: A Foucauldian approach. Organization Studies, 32(9), 1247-1271.

Lewis, J. (2003). Design issues. In J. Ritchie \& J. Lewis (Eds.), Qualitative research practice: A guide for social science students and researchers (pp. 47-76). London/ Thousand Oaks/New Delhi: Sage Publications.

Lewis, J., \& Ritchie, J. (2003). Generalising from qualitative research. In J. Ritchie \& J. Lewis (Eds.), Qualitative research practice: A Guide for social science students and researchers (pp. 263-286). London/Thousand Oaks/ New Delhi: Sage Publications.

Mair, J. (2009). The events industry: The employment context. In T. Baum, M. Deery, C. Hanlon, L. Lockstone, \& K. Smith (Eds.), People and work in events and conventions - A research perspective (pp. 3-16). Oxfordshire/ London: CABI.

McElroy, M. W. (2003). The new knowledge managementComplexity, learning, and sustainable innovation. Amsterdam: Butterworth Heinemann.

McKee, A. (2003). Textual analysis-A beginner's guide. London/Thousand Oaks/New Delhi: Sage Publications.

Meyer, M. (2010). The rise of the knowledge broker. Science Communication, 32(1), 118-127.

Morgan, M. (2009). What makes a good festival? Understanding the event experience. Event Management, 12, 81-93.

Morrison, E. W. (1994). Role definitions and organizational citizenship behavior: The importance of the employee's perspective. The Academy of Management Journal, 37(6), 1543-1567.

Nonaka, I., \& Takeuchi, H. (1995). The knowledge creating company-How Japanese companies create the dynamics of innovation. New York: Oxford University Press.

Nonaka, I., \& Von Krogh, G. (2009). Tacit knowledge and knowledge conversion: Controversy and advancement in organizational knowledge creation theory. Organization Science, 20(3), 635-652.

O'Dell, C. (2004). The executive's role in knowledge management. Houston, TX: APQC Publications.

Osterloh, M., \& Frey, B. S. (2000). Motivation, knowledge transfer, and organizational form. Organization Science, 11(5), 538-550.

Queensland Music Festival. (2011) QMF. Retrieved September 20, 2011, from http://qmf.org.au/

Reid, S. (2008). Identifying social consequences or rural events. Event Management, 11, 89-98.
Richardson, L. (2000). New writing practices in qualitative research. Sociology of Sport Journal, 17, 5-20.

Ritchie, J., Lewis, J., \& Elam, G. (2003). Designing and selecting samples. In J. Ritchie \& J. Lewis (Eds.), Qualitative research practice: A Guide for social science students and researchers (pp. 77-108). London/Thousand Oaks/New Delhi: Sage Publications.

Saukko, P. (2003). Doing research in cultural studies-An introduction to classical and new methodological approaches. London/Thousand Oaks/New Delhi: Sage Publications.

Schütt, P. (2003). The post-Nonaka knowledge management. Journal of Universal Computer Science, 9(6), 451-462.

Seale, C. (1999). The quality of qualitative research. London/ Thousand Oaks/New Delhi: Sage Publications.

Singh, N., \& Hu, C. (2008). Understanding strategic alignment for destination marketing and the 2004 Athens Olympic Games: Implications from extracted tacit knowledge. Tourism Management, 29, 929-939.

Snape, D., \& Spencer, L. (2003). The foundations of qualitative research. In J. Ritchie \& J. Lewis (Eds.), Qualitative research practice: A guide for social science students and researchers (pp. 1-23). London/Thousand Oaks/ New Delhi: Sage Publications.

Suppiah, V., \& Singh Sandhu, M. (2011). Organisational culture's influence on tacit knowledge-sharing behaviour. Journal of Knowledge Management, 15(3), 462-477.

Szulanski, G. (2000). The process of knowledge transfer: A diachronic analysis of stickiness. Organizational Behavior and Human Decision Processes, 82(1), 9-27.

Thatchenkery, T., \& Chowdhry, D. (2007). Appreciative inquiry and knowledge management-A social constructionist perspective. Cheltenham/Northhampton: Edward Elgar.

Tourism and Events Queensland. (2013). How to organize special events and festivals in Queensland (8th ed., originally written by Tonge, R.). Retrieved from http://www. eventsqld.com.au/assets/documents/handbook-howtoorganisespecialevents-8thedition.pdf

Townley, B. (1993). Foucault, power/knowledge and its relevance for human resource management. Academy of Management, 18(3), 518-545.

Van der Wagen, L. (2007). Human resource management for events-Managing the event workforce. Amsterdam: Elsevier.

Wenger, E. (1998). Communities of practice-Learning, meaning, and identity. Cambridge: Cambridge University Press.

Wenger, E., McDermott, R., \& Snyder, W. M. (2002). Cultivating communities of practice. Boston: Harvard Business School Press.

Yahya, S., \& Goh, W.-K. (2002). Managing human resources toward achieving knowledge management. Journal of Knowledge Management, 6(5), 457-468.

Yang, J.-T. (2007). Knowledge sharing: Investigating appropriate leadership roles and collaborative culture. Tourism Management, 28, 530-543. 